\title{
COMMENTS
}

\section{MOOTNESS, THE PARKE, DAVIS CASE AND TREBLE DAMAGE CLAIMANTS}

A defendant's discontinuance of challenged business practices in Government suits for injunction under the antitrust laws has given rise to recurrent jurisdictional problems. The mootness question ${ }^{1}$ in this context has become particularly troublesome in the light of the recent decision in United States $v$. Parke, Davis \& Co.2 This question has importance not only for the Antitrust Division and those defendants who have terminated their challenged practices, but also for that potential beneficiary of a decree for the Governmentthe treble damage claimant. ${ }^{3}$

1 See generally Diamond, Federal Jurisdiction to Decide Moot Cases, 94 U. PA. L. Rev. 125 (1946); Note, Cases Moot on Appeal: A Limit on the Judicial Power, 103 U. PA. L. REv. 772 (1955); Hart \& Wechsler, The Federal Courts and the Federal System \$\$ 1-5 (1953); Robertson \& KirkHAM, JURISDICTION OF THE SUPREME COURT OF THE UNITED STATEs chs. 33, 36 (Wolfson \& Kurland ed. 1951).

2365 U.S. 125 (1961).

3 In order to facilitate recovery by individual victims of violations of the antitrust laws, Congress enacted Section 5(a) of the Clayton Act, 69 Stat. 283 (1955), 15 U.S.C. \$16(a) (1958), providing that: "A final judgment or decree heretofore or hereafter rendered in any civil or criminal proceeding brought by or on behalf of the United States under the antitrust laws to the effect that a defendant has violated said laws shall be prima facie evidence against such defendant in any action or proceeding brought by any other party against such defendant under said laws or by the United States under section 15a of this title, as to all matters respecting which said judgment or decree would be an estoppel as between the parties thereto: Provided, That this section shall not apply to consent judgments or decrees entered before any testimony has been taken or to judgments or decrees entered in actions under section 15a of this title."

For many years section 5(a) was virtually useless. See Note, 32 CoLUM. L. REv. 335, 342-43 (1932); Comment, 49 Y ALE L.J. 284, 296-99 (1939). This situation has changed considerably as courts have defined the possible uses of prior government decrees. See, e.g., Emich Motors Corp. v. General Motors Corp., 340 U.S. 558 (1951). Now, the major obstacles to the effective use of section 5(a) are: (1) the length of time a private party must wait before judgment in the Government suit becomes final, and (2) the fact that the proviso in section 5(a) makes consent decrees and nolo contendere pleas inadmissible in private suits. On the nolo plea see Barnsdal Ref. Corp. v. Birnamwood Oil Co., 32 F. Supp. 308 (D. Wis. 1940); Twin Ports Oil Co. v. Pure Oil Co., 26 F. Supp. 366, 370-79 (D. Minn. 1937). In Phillips, The Consent Decree in Antitrust Enforcement, 18 WASH. \& LEE L. REv. 39, 42 (1961), it was said that between 1955-1959, 79 per cent of all civil cases were settled by consent. But the Government can refuse to consent if an adjudication is desired. Judgments in criminal cases may be used under section 5(a), though with somewhat more difficulty than civil decrees, since ordinarily in criminal cases no findings of fact are made. Pleas of nolo contendere, however, may deprive private claimants of a useful judgment. Though the Government may object to such a plea, acceptance is in the hands of the court. FED. R. CRIM. P. 11. Compare United States v. Safeway Stores, Inc., 20 F.R.D. 451 (N.D. Tex. 1957), with United States 
A Government suit to enjoin antitrust violations under section 4 of the Sherman Act ${ }^{4}$ may be deemed moot if the alleged violations are terminated. That termination of violative practices may occur, before or during trial, because of supervening events, as in United States v. Hamburg-American Co., 5 or by voluntary acts of the defendants, as in United States v. Standard Oil Co.6 Mere cessation of allegedly wrongful acts often does not, however, relieve the court of power to hear and decide the case. In United States v. Trans-Missouri Freight $A s s^{\prime} n^{7}$ the Court held that a voluntary dissolution of a violative agree-

v. Standard Ultramarine \& Color Co., 137 F. Supp. 167 (S.D.N.Y. 1955) for opposing views on how potential treble damage suits should affect the court's decision on whether to accept a nolo plea. See also Timberlake, The Use of Government Judgments or Decrees in Subsequent Treble Damage Actions under the Antitrust Laws, 36 N.Y.U.L. REv. 991 (1961); Comment, Antitrust Enforcement by Private Parties: Analysis of Developments in the Treble Damage Suit, 61 Yale L.J. 1010 (1952); Note, Clayton Act, Section 5: Aid to Treble Damage Suitors? 61 YALE L.J. 417 (1952).

439 Stat. 1167 (1911), 15 U.S.C. $\$ 4$ (1958). "The several district courts of the United States are invested with jurisdiction to prevent and restrain violations of sections 1-7 of this title; and it shall be the duty of the several United States attorneys, in their respective districts, under the direction of the Attorney General, to institute proceedings in equity to prevent and restrain such violations. Such proceedings may be by way of petition setting forth the case and praying that such violation shall be enjoined or otherwise prohibited...."

5239 U.S. 466 (1916). The Government challenged an agreement between American, Canadian, and European shipping companies, including German lines, as violative of the antitrust laws. Both plaintiff and defendants appealed to the Supreme Court from the district court ruling that although the main agreement was not violative, a subsidiary agreement was. The Supreme Court held the case moot "as an inevitable legal consequence" of the First World War. Id. at 475. The necessary withdrawal of the German companies dissolved the agreement by its terms. In answer to the Government's argument that the companies probably would renew their compact at the end of the war and that therefore the issue was not moot, the Court relied on the involuntary nature of the termination. On this ground it distinguished two earlier cases which had held that the cessation of wrongs did not render those cases moot. See notes 6 \& 7 infra. See also United States v. Alaska S.S. Co., 253 U.S. 113 (1920) (suit to enjoin I.C.C. from regulating certain forms of bills of lading held moot when statute enacted necessitated changes in those bills of lading); United States v. American-Asiatic S.S. Co., 242 U.S. 537 (1917) (agreement between American, British, and German steamship companies dissolved as a legal consequence of war; held moot following Hamburg).

6283 U.S. 163, 181-82 (1931). The Government objected to certain early licensing agreements which contained territorial restrictions and to blanket acknowledgments of patent validity in a contract. The challenged provisions, never having been enforced, were cancelled by defendant during trial at the district judge's request. In holding the case moot, the Court rejected the distinction between voluntary and involuntary terminations. See also United States v. W. T. Grant Co., 345 U.S. 629 (1953) (voluntary resignation of interlocking director during suit); Walling v. Shenandoah-Dives Mining Co., 134 F.2d 395 (10th Cir. 1943) (voluntary cancellation of challenged contracts six months after suit filed: held moot); United States v. William S. Gray \& Co., 59 F. Supp. 665 (S.D.N.Y. 1945) (defendant corporation sold its asserts and dissolved: held moot); Walling v. Lacy, 51 F. Supp. 1002 (D. Colo. 1943) (voluntary cessation of admitted violations: held moot).

7166 U.S. 290 (1897) (association of railroads to establish and maintain rates, rules and regulations for all their freight traffic dissolved after favorablé judgment in district court). 
ment without assurance as to the future, where it was in the hands of the defendants to renew their offensive conduct at will, did not deprive the Court of jurisdiction. Otherwise a defendant might continually defeat judicial action by temporarily discontinuing offensive practices. In an analogous situation in which a railroad sued to enjoin the enforcement of allegedly invalid shortterm orders of the Interstate Commerce Commission, the Court held that expiration of the contested order did not render the case moot. ${ }^{8}$ Such shortterm orders were usually renewed as a matter of course at expiration. To have decided otherwise would have been to hold that no appellate review of such an order was possible, if only because of the normal lapse of time before cases reach appellate courts.

Cases which arose during the Second World War have further refined the mootness doctrine in situations where wrongful practices have been terminated. One aspect of United States v. National Lead Co. ${ }^{9}$ would appear, at first glance, to be on all fours with that part of the Standard Oil10 case relating to mootness. In both cases the defendants voluntarily cancelled challenged agreements during trial. In Standard Oil the cancelled provisions had never been enforced, and, because of technological changes, would in all likelihood never have been enforced in the future. The provisions voluntarily cancelled in National Lead 11 appeared to the court to be more vital to the defendants. The district court held, and the Supreme Court tacitly agreed, that the voluntary cancellation here did not render the case moot. Cancellation was only a fact to be considered in deciding on the likelihood of resumption of illegal practices. 12 This decision is consonant with the rule stated by Judge Learned

8 Southern Pac. Ry. v. I.C.C., 219 U.S. 433 (1911).

963 F. Supp. 513, 526-27 (S.D.N.Y.), aff'd, 332 U.S. 319 (1947). The Government attacked defendants" "patent pool" agreements as being in restraint of trade. During the trial the contracts between National Lead, an American company, and the British and Canadian companies were revised and new contracts proposed. The district court felt that this only indicated a disposition to abandon illegal practices and did not prove abandonment.

10283 U.S. at 181-82.

1163 F. Supp. at 526-27.

12 Ibid. See United States v. United States Steel Corp., 251 U.S. 417, 445 (1920). Cf. Swift \& Co. v. United States, 196 U.S. 375, 396 (1905). In United States v. W. T. Grant Co., 345 U.S. 629, 632-33 (1953) a distinction was drawn between (1) suits in which the defendant is able to show that no reasonable expectation of resumption exists, (2) suits in which the plaintiff shows that some mere possibility of resumption remains, and (3) suits in which there remains something more than a mere possibility of resumption. The first situation was said to be moot; the second was not moot but no injunction was warranted; and the third required an injunction. Thus three degrees of probability of resumption are suggested. The Hamburg and Standard Oil cases fit into the first category. In both cases, resumption of the wrongs was possible in the future but highly improbable. W. T. Grant was held to be in the second category (and hence the language in that case about mootness is dictum). The Aluminum case, National Lead, and Trans-Missouri were all in the third category. In the first two the courts were not persuaded that the defendants would not resume their practices immediately. In Trans-Missouri the defendant association was dissolved. The association as a legal entity was gone, but many of the individual members of the defunct association had already formed a new association, designed to operate in the same way as the old. 
Hand in United States v. Aluminum Co. of America.13 In that case war had interrupted business dealings between American, Canadian, and European corporations. The First World War had interrupted dealings in the Hamburg case. Unlike that case, however, in the Aluminum case war did not result in formal cancellation of the agreement. On this ground Judge Hand distinguished the two cases, 14 stating that, "The mere cessation of an unlawful activity before [or after] suit does not deprive the court of jurisdiction to provide against its resumption; a 'case or controversy' may remain to be disposed of. ... To disarm the court it must appear that there is no reasonable expectation that the wrong will be repeated."'15 Thus mootness is defined not in terms of involuntary cessation, as in Hamburg, nor in terms of absolute cessation, voluntary or involuntary, , but rather as dependent only upon the likelihood of resumption. Some question may arise, however, as to whether a case is really moot if resumption of voluntarily discontinued violations is not impossible.

In Muskrat v. United States 16 the Supreme Court said that the "judicial power ... is the right to determine actual controversies arising between adverse litigants." 17 Adversity of interest might outlast the termination of violations. The plaintiff could assert a right to be protected from the possibility, however small, that the defendant might again take up his wrongful practices. The plaintiff's interest could be effectively protected by enjoining the offenses. It might, then, be more appropriate to say that such a case is not moot, but rather that the court merely has exercised its discretion to dismiss the case as a result of plaintiff's failure to satisfy it that relief is necessary. Traditionally courts with equitable powers have been reluctant to grant injunctions in the absence of a strong showing of continuing or of imminent "irreparable" injury. ${ }^{18}$ That the injury inherent in restraint of trade is "irreparable" is clear from Congress' authorization to grant an injunction to prevent and restrain any violation of the antitrust laws. But the traditional requirement of imminence is not met when the plaintiff is able to show only a mere possibility of resumption. Thus dismissal would seem to be required, at least, by normal principles of equitable discretion.

But to say that a suit for injunction never becomes moot on termination of the wrongs sought to be prohibited unless resumption is impossible would be

13148 F.2d 416, 447-48 (2d Cir. 1945) (sitting as court of last resort because a quorum of the Supreme Court was not available to hear the case).

14 The court's treatment of the jurisdictional question was a part only of a longer opinion involving problems of substantive antitrust law.

15148 F.2d at 448.

16219 U.S. 346 (1911).

17219 U.S. at 361 . See generally ROBERTSON \& KIRKHAM, op. cit. supra note 1, at $\$ \$ 260$, $271,286$.

18 See $2 \mathrm{HIGH}$, InJUNCTIONS $\$ 22$ (2d ed. 1880); United States v. Oregon State Medical Soc'y, 343 U.S. 326, 333 (1952). 
extraordinary. It is settled that "when an injunction is sought against enforcement of an enactment, the repeal or vital amendment of that statute pending appeal may in a real sense, convert the case into a moot one."19 The plaintiff in such a suit might feel, however, that repeal was a sham and that substantially the same statute was going to be reenacted immediately. Reenactment clearly is not an impossibility. A dispute over the validity of the statute would thus remain. 20

In the case of a repealed or amended statute the court must deal with a problem very similar to that in an antitrust case in which a defendant has shown that there is no reasonable expectation of resumption of terminated practices. If the repealed statute case is moot, it is not because the need for judicial action has been eliminated, but because the need has been so diminished as to become negligible. The difference between the two cases would seem to lie in the courts' tacit, or sometimes express,21 assumption that repealed or amended statutes will not be reenacted. Such an assumption cannot be made about business practices. The requirement that alleged antitrust violators establish a high degree of improbability of resumption replaces the assumption of legislative good faith and responsibility. There are practical reasons why courts should not decide such cases. While there may be no doubt in an antitrust case that the parties' interests remain adverse after cessation of violations, the actuality of the original controversy has disappeared. Neither party has anything to gain directly from decision of the case. The purpose of a suit for injunction is to correct wrongful behavior. 22 Self-correction

19 RoberTSON \& KIRKHAM, op. cit. supra note 1, at 528. See United States v. Alaska S.S. Co., 253 U.S. 113 (1920).

20 It might be suggested that this situation is not analogous. The case may be said to be moot because the statute whose enforcement was sought to be restrained has been repealed, and that particular statute can never be reenacted. Any statute then passed, even one identical to the old one, would be a new law. The controversy involving the old statute would then be moot. This formal approach, however, also applies to business activities. The dissolution of a particular association, for example, puts that particular association out of existence. A new agreement will not breathe life into the old form. But cf. United States v. Aluminum Co. of America, 148 F.2d 416, 447-48 (2d Cir. 1945). See text at note 8 supra.

See Clark v. Flory, 141 F. Supp. 248, 250 (E.D.S.C.), aff'd per curiam, 237 F.2d 597 (4th Cir. 1956). This was a suit for a declaratory judgment of the right of the Negro plaintiffs to use state park facilities. During the litigation the state legislature closed the park. The district court held the case moot. The plaintiffs had argued that the legislature could order the reopening of the park for the use of whites only and in case of further litigation simply close the park again. The district court said, "I cannot, and will not, assume that the Legislature of South Carolina would do such a thing. ... It would be a reflection on the honesty and integrity of this honorable body to assume that they would open and close the park ... [to] circumvent the rights of the plaintiffs and other Negroes to use the park." Id. at 250 . This being a segregation case, there may be danger in generalizing too freely from it.

21 See note 20 supra. But cf. Tate v. Department of Conservation and Dev., 133 F. Supp. 53 (E.D. Va. 1955); Lawrence v. Hancock, 76 F. Supp. 1004 (S.D.W. Va. 1948).

22 "The sole function of an action for injunction is to forestall future violations. It is so unrelated to punishment or reparations for those past that its pendency or decision does not prevent concurrent or later remedy for past violations by indictment or action for dam- 
sufficed for that. A defendant who has given up challenged practices without the need or intention of resuming them would appear to have little interest in the immediate case in establishing the validity of the discontinued acts. The decision of such a case would have practical results only in future litigation.

It is also arguable in some suits under the antitrust laws that the Government may not be as interested in winning an injunction as in aiding private litigants. ${ }^{23}$ When challenged practices have been terminated without significant danger of renewal, ${ }^{24}$ this possibility may become quite real. Section 5(a) of the Clayton $\mathrm{Act}^{25}$ provides that those injured by antitrust violations may rely on certain decrees in prior government suits as prima facie evidence in treble damage suits under Section 4 of the Clayton Act. 26 If the Government's purpose directly to prevent and restrain violations of the antitrust laws shifts so that the purpose is merely to help private litigants in their suits, it could be said that the interests of the parties to the original suit are no longer adverse. The Government would not benefit by a favorable decision. Rather the benefit would run to the third parties who might thereafter prosecute separate treble damage suits against the defendants. In the past, if a defendant could show that no reasonable expectation of the renewal of terminated wrongs existed, he did not have to fear that treble damage claimants could benefit from the Government's case. The defendant could be fairly confident that the case would be dismissed as moot. ${ }^{27}$ Private claimants could not benefit therefore

ages by those injured. All it takes to make the cause of action for relief by injunction is a real threat of future violation or a contemporary violation of a nature likely to continue or recur." United States v. Oregon State Medical Soc'y, 343 U.S. 326, 333 (1952). Accord, United States v. W. T. Grant Co., 345 U.S. 629, 633 (1953); Hecht Co. v. Bowles, 321 U.S. 321, 329 (1944). AtT'y GEN. NAT'L Comm. ANTITRUST Rep. 364 (1955). See 2 High, InJUNCTIONS § 1 (2d ed. 1880); 2 STORY, EQUITY §§ 861, 862 (13th ed. 1886).

.23 In certain situations, primarily where state or municipal governmental units have been injured by collusive bidding, Acting Assistant Attorney General Bicks, in charge of the Antitrust Division, has publicly asserted that the Division's policy is to make every effort to win a judgment useful to treble damage claimants. Wall Street Journal, March 14, 1960, p. 26. See United States v. Brunswick-Balke-Collender, civil No. 59 C 163 (D. Wis. March 27, 1962). The Antitrust Division contested entry of a consent decree which did not include an adjudication to the effect that the defendants had violated Section 1 of the Sherman Act, the adjudication to be admissible as prima facie evidence in private treble damage suits. The district court rejected the Government's argument, concluding that the consent decree, in enjoining all objectionable acts of the defendants, performed its function. The Government's insistence on a decree useful to private litigants "constitutes arbitrary and unauthorized conduct."

24 I.e., when there is either no reasonable expectation of resumption or only a mere possibility. See note 12 supra.

2569 Stat. 283 (1955), 15 U.S.C. $\S 16(a)(1958)$. See note 3 supra.

2669 Stat. 283 (1955), 15 U.S.C. § 4(1958). See note 4 supra.

27 See cases cited in note 6 supra and note 12 supra. See also Walling v. Shenandoah-Dives Mining Co., 134 F.2d 395, 397 (10th Cir. 1943) where it was held that a suit for injunction cannot be used to punish or "to simply establish that violations had occurred." See United 
from findings as to past violations. The decision in United States v. Parke, Davis \& Co. ${ }^{28}$ should, however, shake defendants' confidence.

II

In the Parke, Davis ${ }^{29}$ case the Supreme Court passed on the question of past violations though no injunctive relief was ordered. The Government brought suit under Section 4 of the Sherman Act ${ }^{30}$ to prevent and restrain violation of sections 1 and 331 of that act. At the close of the plaintiff's case, the district court dismissed when it found that no violations had been shown. Alternatively the district court held that even had violations been shown the case would have been dismissed. The challenged practices had been given up before suit, and there was no substantial probability of resumption. 32 The Supreme Court reversed, holding that the Government had established a prima facie case. The Court also held that there was nothing in the record to justify the lower court's finding that no substantial probability of resumption existed. The case was remanded with direction to enjoin Parke, Davis from further violations unless the company refuted the Government's right to an injunction. 33

On remand Parke, Davis chose to argue only that since the violative practices had been completely terminated, no injunction should issue. Parke, Davis introduced evidence on this point but did not dispute the Government evidence as to past violations. Again the district court dismissed, refusing to enjoin Parke, Davis or to adjudge that the company had in the past violated the act. ${ }^{34}$

In the Supreme Court again, the Government, no longer seeking an injunction, ${ }^{35}$ contended that the district judge should have adjudged the defendant guilty of past violations. The plaintiff did not suggest that the trial court was wrong in deciding that there was no likelihood of resumption. The Court reversed, per curiam, ordering that the plaintiff was entitled to a judgment on

States v. Logan Co., 147 F. Supp. 330 (W.D. Pa. 1957); United States v. Insurance Bd., 144 F. Supp. 684, 691-95 (N.D. Ohio 1956). See generally ROBERTSON \& KIRKHAM, op. cit. supra note $1, \S 286$.

28365 U.S. 125 (1961).

29 On the problems of substantive law in the case see Levi, The Parke, Davis-Colgate Doctrine: The Ban on Resale Price Maintenance, 1960 SuP. Cr. Rev. 258.

3062 Stat. 909 (1948), 15 U.S.C. $\$ 4$ (1958).

3169 Stat. 282 (1955), 15 U.S.C. $\S \S 1,3$ (1958).

32164 F. Supp. 827, 835-36 (D.D.C. 1958).

33362 U.S. 29 (1960).

34 Trade Reg. ReP. (1960 Trade Cas.) If 69, 776 (D.D.C. July 18, 1960).

35 In its Jurisdictional Statement to the Supreme Court the Government specifically agreed to the district court's denial of injunctive relief. Statement as to Jurisdiction, p. 8, n. 4, United States v. Parke, Davis \& Co., 365 U.S. 125 (1961). 
the merits to the effect that the defendant had violated the act. The district court was to retain the case on its docket in case injunctive relief might be necessary in the future. ${ }^{36}$ Thus the judgment was made available to private litigants as prima facie evidence of violation. Moreover, a major modification of the substantive law relating to resale price maintenance was established. ${ }^{37}$

III

The Supreme Court per curiam decision was without citation of authority. The case is not so clear as to warrant such summary treatment. Even if it was not really moot, the federal courts in the past usually acted in accordance with the dictum in United States v. Aluminum Co. of America: "Unless we are to grant an injunction, we ought not pass upon the issue." 38 In order to evaluate the question of mootness in the case, the Antitrust Division's claims as found in its Jurisdictional Statement and Brief should be examined.

Most of the Government's points are made in the Jurisdictional Statement. In order to impress upon the Court the substantiality of the issue, three major arguments were presented. In the order found in the Statement they are: (1) The decision in the district court would weaken the congressional plan to make the private suit an important part of antitrust enforcement. Without an adjudication treble damage claimants might have to relitigate questions of violation which had been decided in the Government suit. ${ }^{39}$ (2) Government litigation would also be affected. Congress has authorized the Government's use of its own prior judgments in damage suits under Section 4(a) of the Clayton Act. 40 (There was, however, no question in this case of damage to the Government.) Moreover, if the defendant renewed the challenged practices the Government might have to relitigate the issues decided in the present case.41 Finally, the consent decree mechanism would be weakened if defendants felt that they couid go to trial and lose on the question of legality but prevent an adjudication by showing that no injunction should issue. 42

36 The procedure of retaining a case on the court's docket was followed in United States v. Appalachian Coals, Inc., 288 U.S. 344, 377-78 (1933). In that case the challenged agreement had been published, but not yet put into operation. The Supreme Court said that the plan was not a per se violation of the antitrust laws, but that in operation it might prove violative. The Court dismissed the suit without prejudice to the United States and directed the district court to retain jurisdiction so that if the plan should prove violative, relief might then be given.

37 See Levi, supra note 29.

38148 F.2d at 448. See United States v. W. T. Grant Co., 345 U.S. 629 (1953); United States v. Insurance Bd., 144 F. Supp. 684, 695-96 (E.D. Ohio 1956). Cf. United States v. Oregon State Medical Soc'y, 343 U.S. 326, 333-34 (1952).

39 Statement as to Jurisdiction, pp. 9-11, United States v. Parke, Davis \& Co., 365 U.S. 125 (1961).

40 Id. at $11-12$.

41 Id. at 12.

42 Id. at 12-13. This argument goes to the question of saving time and expense. The consent decree mechanism might also, however, be weakened by the adjudication 
(3) The district court's duty is to "prevent and restrain" violations of the antitrust laws. The court is thus obliged to adjudicate that there was a violation.43 Without such an adjudication the usefulness of Section 5(a) of the Clayton Act, which contemplates that judgments in Government suits will contain an adjudication of defendant's violations, would be lessened.44 The Government also made passing reference to the Declaratory Judgment Act.45

The district court had not dismissed the case as moot despite finding no reasonable probability of resumption of the wrongs. In its Brief the Government contended that the district court was correct because a controversy remained as to whether the court should adjudicate. ${ }^{46}$ The Government's full 47 conclusion follows:

The basic objective of Section 5 of the Clayton Act-"to minimize the burdens of litigation for injured private suitors by making available to them all matters previously established by the Government in antitrust actions" (Emich Motors v. General Motors, 340 U.S. 558, 568)-would be thwarted if, as appellee contends, an antitrust defendant can contest the alleged violation at trial but, if it loses, still avoid the consequences of an adjudication that the statute contemplates. 48

The Government clearly wanted to help private litigants. It is equally clear that an injunction was no longer claimed. If the purport of the suit is merely to establish prima facie evidence for private suitors, it should be dismissed as moot. That situation would be analogous to a suit to prevent infringement or threatened infringement of a valid patent.49 If the court rules that the patent is invalid and not infringed or threatened with infringement, a party cannot appeal only the issue of validity. This is true, in spite of the public

called for here. It seems probable that the Antitrust Division would be less likely to consent if there were more chance to help the private litigant. Therefore, the time saved in later private actions by application of Section 5(a) might be lost in the original Government suit. A suit which prior to Parke, Davis could have been concluded by a showing that discontinuance had eliminated the need for an injunction will now be extended by defense of past behavior. Also, since the judgment in the Government suit has only prima facie effect in private suits, the defendant could defend them as vigorously as he had the original suit. The procedure in Parke, Davis should always save time for later private plaintiffs. But it probably will not save time for defendants, and it will probably mean that the Government will spend more time in the original suit.

${ }^{43} \mathrm{Id}$. at 13. It should be noted that the statute specifically authorizes only a prayer for injunction or other prohibition. This could be taken to mean that the statute contemplated not a mere adjudication, but rather coercive relief. See Walling v. Shenandoah-Dives Mining Co., 134 F.2d 395 (10th Cir. 1943) and note 27 supra. Cf. cases note 22 supra.

44 Statement as to Jurisdiction, p. 14.

45 Id. at 13.

46 Brief for Appellant, pp. 5-6, United States v. Parke, Davis \& Co., 365 U.S. 125 (1961).

47 The prayer for judgment is omitted.

48 Brief for Appellant, p. 7.

49 See Cover v. Schwartz, 133 F.2d 541 (2d Cir. 1942). 
interest in determining the validity of patent monopolies, because "the holder of a patent has no dispute with a person who is not infringing or threatening to infringe."'so A federal court is "not empowered . . . to declare, for the government of future cases, principles or rules of law which cannot affect the result as to the thing in issue in the case before it." 51 An adjudication, therefore, should not be made only for ulterior purposes. 52 When an injunction is no longer sought, no rights which the Government was appointed to protect will be protected. Nor will the earlier invasion of those rights be vindicated by a bare adjudication of violation. 53 No case or controversy exists when all that is sought from the court is its opinion on the legality of past acts. 54

In the Jurisdictional Statement the Government suggested that the controversy was still vital since Parke, Davis might at any time renew its wrongful practices. It is submitted, to the contrary, that the Hamburg5s and Standard Oil 56 cases, taken in conjunction with the Aluminum ${ }^{57}$ and National Lead 58 cases, state a rule which, unless overruled, should have been applied to render the case moot. Parke, Davis gave up the offensive practices before the suit was filed and did not resume them even after a favorable decision in a companion criminal case. 59 There were, according to the district judge, sound business reasons for Parke, Davis' eschewing the offenses in the future.60 The judge concluded that there was no reasonable expectation that Parke, Davis would renew the violations. The Antitrust Division did not contest the defendant's evidence, and, in relinquishing its demand for injunctive relief, the

so Id. at 545.

si California v. San Pablo \& T. R.R., 149 U.S. 308, 314 (1893).

52 In United States v. William S. Gray \& Co., 59 F. Supp. 665 (S.D.N.Y. 1945), the case against one of a number of defendants was dismissed. The court specifically rejected the Antitrust Division's argument that that defendant ought to be kept in the case for the benefit of future treble damage claimants. "It does not seem to me that these defendants should be subjected to ... trial when the basis for relief demanded in the complaint no longer exists and the sole purpose is an ulterior one.... It should also be remembered that the purpose of the suit at bar is to prevent future wrongful acts and that a triple damage suit is to recover for wrongful acts in the past." Id. at 667. Cf. ROBERTSON \& KIRKHAM, op. cit. supra note $1, \S 298$ : "Standing to invoke adjudication is lacking where the right sought to be championed is that of third parties."

53 Cf. Wallace v. Nashville, C. \& St. L. Ry., 288 U.S. 249, 264 (1933).

54 See California v. San Pablo \& T. R.R., 149 U.S. 308, 314 (1893). Cf. United-States v. Muskrat, 219 U.S. 346 (1911). It could be said that there was adversity at the inception of the suit and that only when the Government relinquished its claim for injunctive relief did the controversy lose its adversary nature. In these terms there appears to be real waste in forcing relitigation of issues thoroughly presented before and examined by the courts. On the relevance of this to treble damage suits, see Note, 61 YALE L.J. 417, 425-26(1952) where it is argued that the issues litigated in Government suits should be conclusive in subsequent litigation.

55 239 U.S. 466 (1918).

56283 U.S. 263 (1931).

57148 F.2d 419 (2d Cir. 1945).

5863 F. Supp. 513 (S.D.N.Y. 1946).

59 Trade REg. ReP. (1960 Trade Cas.) If 69, 776, at 77, 073 (D.D.C. July 18, 1960).

60 Ibid. 
Division apparently acquiesced in the trial court's conclusion. The HamburgStandard Oil doctrine was designed for such a case as this. In Hamburg the Government, still seeking an injunction, argued strenuously that the illegal activities could and probably would be renewed as soon as the war ended.61 In Standard Oil the Government contended that repentance had come too late to have been in good faith.62 Yet in both cases the issue was deemed moot. The Government or private parties might have to relitigate similar issues of law in a later case. But this is necessarily true whenever a controversy is moot. No more persuasive is the argument that the court had power under the Declaratory Judgment Act ${ }^{63}$ to decide the case. The requisites for justiciability in a suit for declaratory judgment are at least as strict as in a normal suit.64 The defendant must have an interest in opposing the plaintiff's claim, and the "danger or dilemma of the plaintiff must be present, not contingent on the happening of hypothetical future events ... and the prejudice to his position must be actual and genuine and not merely possible or remote." 65 It is clear that Parke, Davis' resumption of the wrongs was at best "merely possible." The Supreme Court has never retained jurisdiction of an antitrust suit merely to settle a dispute over the legality of discontinued practices. 66

\section{CONCLUSION}

If the Supreme Court retained jurisdiction of the Parke, Davis case and decided it because of the possible need for future injunctive relief, the Court failed to exercise its power properly. Only undue uncertainty can result from the Court's disregarding its earlier decisions. The same reasons for finding mootness where resumption of violations is impossible largely apply where the likelihood of resumption is negligible. 67 On the other hand it might easily be inferred from the Government's Jurisdictional Statement and Brief that the

61239 U.S. at 475.

62 Brief for Appellee, United States v. Standard Oil Co., 283 U.S. 163 (1931).

6328 U.S.C. $\$ 2201$ (1958).

${ }^{64}$ Since a court has discretion to refuse to decide a suit for declaratory judgment even when there is a controversy which in an ordinary proceeding would be justiciable, it might be said that the requirements for justiciability are stricter. See BORCHARD, DECLARATORY JUDGMENTS 312-14 (2d ed. 1941). Whether a declaratory judgment would be an appropriate remedy here is questionable in view of Mr. Justice Frankfurter's dictum in Colegrove v. Green, 328 U.S. 549, 552 (1946): "The test for determining whether a federal court has authority to make a declaration ... is whether the controversy 'would be justiciable in this Court if presented in a suit for injunction...." "For criticism of this statement see Note, 56 YALE L.J. 139 (1946). See generally HART \& WeCHSLER, op. cit. supra note 1, at 126-56.

65 BORCHARD, op. cit. supra note 64, at 56.

$66 \mathrm{It}$ is often said that when a dispute over the legality of terminated practices remains, the case is not moot. See, e.g., United States v. W. T. Grant Co., 345 U.S. 629, 632 (1953). No case has been found, however, in which the sole ground for retaining jurisdiction was to settle such a dispute. See, e.g., Walling v. Helmerich \& Payne, Inc., 323 U.S. 37 (1944). See Diamond, supra note 1, at 139-40.

67 l.e., when there is no reasonable expectation of resumption. See note 12 supra. 
needs of private litigants and not the possibility of further violation prompted the Division's insistence on an adjudication of past violations. If that inference is proper, the Supreme Court should have dismissed the case as moot. Private litigants deserve help; the settlement of open questions of law is desirable for the sake of certainty; but traditional principles forbid the resolution of issues where there is no case or controversy between the immediate parties to the suit. 